\title{
State Financing of Environmental Investment Projects
}

\author{
Sotnikova L.* \\ Finance and credit Department \\ Voronezh State Agrarian University named after Emperor \\ Peter I \\ Voronezh, Russia \\ e-mail: lyusotn@yandex.ru
}

\author{
Bichyova E. \\ Finance and credit Department \\ Voronezh State Agrarian University named after Emperor \\ Peter I \\ Voronezh, Russia \\ e-mail: elenabicheva@yandex.ru
}

\begin{abstract}
The article considers the state financing features of investments. The changes trends in the volume of investments in fixed assets aimed at environmental protection and rational natural resources use, as well as the structure of sources of their financing for 2010-2019 are revealed. The authors assess the condition and problems of subsidizing "green" bonds and state support for the green Finance market in the Russian Federation. Based on the assessment, alternative measures are proposed to improve the effectiveness of attracting environmental credit accommodation to Finance environmental investment projects.
\end{abstract}

Keywords - environmental investments, environmental sources of support investment projects, "green" bonds, state support, environmental regulation, subsidizing.

\section{INTRODUCTION}

The state offers various mechanisms for economic incentives for the implementation of environmental measures. Let's pay attention to the measures that support investment at the Federal and regional levels, as well as special tools for developing support and interaction between the state and the investor.

In the "Fundamentals of state policy in the field of environmental development of the Russian Federation for the period up to 2030", approved by the President of the Russian Federation on 30.04.2012, as a strategic goal of state policy in the field of environmental development, it is planned to solve socio-economic problems that ensure environmentally oriented economic growth and the preservation of a favorable environment. Achieving these goals is largely determined by investing in environmentally safe environmental management, which requires the development of a methodology for attracting investment in the implementation of environmentally oriented projects and programs. The implementation of such projects is a means to diversify the economy, promote the introduction of the best available environmentally friendly technologies, and create new industries or industries that replace environmentally hazardous activities.

The development of an effective mechanism for attracting investment in environmentally oriented investment projects and programs will reduce the sharpness of contradictions between production and environmental goals. In this regard, the research topic is related to the implementation of the main provisions of the Federal law of the Russian Federation "on environmental protection", the Environmental doctrine of the
Russian Federation, the Decree of the President of the Russian Federation on the basics of state policy in the field of environmental development, which is of important theoretical and practical significance.

\section{A. Ease of Use}

This Environmental regulation is a system of active legislative, administrative and economic measures and levers that are used by public authorities at various levels to force environmental pollutants to limit emissions of harmful substances into natural and man-made environments, as well as to provide material incentives to conscientious nature users.

Numerous features and diversity of environmental activities and projects make it necessary to systematize and classify environmental investments. The authors ' publications on this subject indicate the relevance of the problem under study.

Industry and agriculture are areas where there can be a transition to new technologies of course, not in order to reduce the negative impact on the environment, and not to fight global warming. Private Russian business and any other business thinks first of all about its profit and about reducing operating costs, which is an increase in production volume and improving the quality of products. In agriculture, much attention is paid to water. The transition to new technologies related to irrigation, for example, drip irrigation, brings much better results in terms of production volumes and quality, and much lower water costs.

\section{RESULTS}

International experience shows that the task of ensuring global food security requires the effective use of all sources of financing, both public and private, in order to effectively and dynamically develop the agricultural sector. In Russian agricultural production, various measures of state support are used, similar to those in other developed countries. The main directions of this support are set out in the "State Program for Development of Agriculture and Regulation of Agricultural Commodity Markets for 2013-2020". [2]

One of the main directions of this program is the development of science and innovation in the field of agroindustrial complex. [2] 
In $2019,7,618.9$ million rubbles were allocated to support agriculture including 4,962. 8 million rubbles from the Federal budget and 2,656. 1 million rubbles from Regional budgets.

The structure of the disposition of funds is in figure 1.

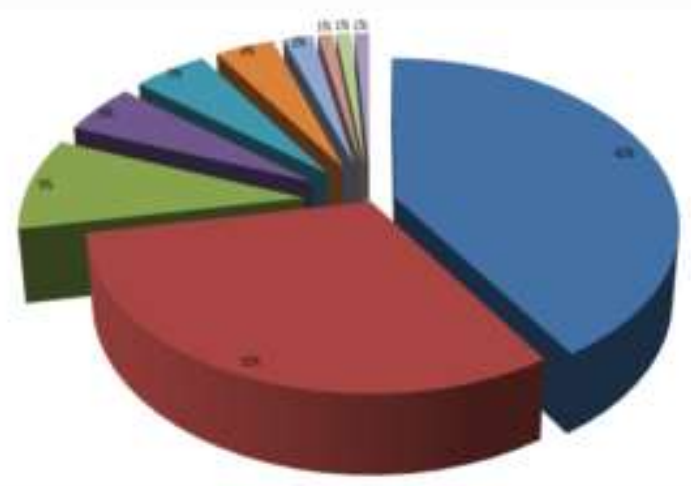

$41 \%$ - Subsidies on investment credit (the Department reimburses part of the interest rate on old loans taken out before January 1, 2017)

$31 \%$ - Assistance in achieving agribusiness development targets ("single" subsidy in 22 areas)

$9 \%$ - Development of the food and processing industry

$5 \%$ - Increase in productivity in the dairy sector, which is 356.2 million rubbles

$5 \%$ - Particularly significant investment projects

$4 \%$ - Unrelated support

$2 \%$-development of amelioration

$1 \%$ - CAPEX

$1 \%$ - Technical and technological modernization

$1 \%$-Creation of a support system for farmers and rural cooperation development.

Fig. 1. Distribution of funds structure to support agriculture in 2019

A particularly promising form of state support of innovative and investment activities of the agricultural regions is the provision of consolidated subsidies, which includes support for short-term credit insurance, small farms, breeding and insurance, as well as variety entertainment of managing and selection, linked also with the development of traditional regions of agriculture (uniform subsidy) [1].

Ecologically (environmental, environmental protection) projects are a special type of investment projects that are distinguished by their clear focus on environmental protection, as well as the rational use of natural resources. Environmental projects are projects aimed at reducing the impact of anthropogenic activities on the environment and the quality maintaining of the environment [7].

Table 1 shows the volume and structure of investments in fixed assets aimed at environmental protection and rational use of natural resources.

As we can see from the table, the volume of investments in fixed assets aimed at protecting the environment and rational use of natural resources for 2010-2018 increased by $77 \%$, while investments in air protection are increasing more dynamically - by 2.5 times. As for the structure of these investments, the largest relative share in environmental measures in 2018 is taken by these investments (for air purification) $-41.5 \%$, which is $12.2 \%$ more than in 2010 [6].

The national projects and the May Decree of the President of Russia set ambitious goals in the environmental sphere, which require active development of green financial instruments, including encouraging the attraction of funds from extra-budgetary sources. In particular, within the framework of the national project "Ecology", it is necessary to attract extra-budgetary funding in the amount of 3.2 trillion rubbles. [3] that is why it is necessary to carefully study the tools for attracting these funds, as well as measures of state support for investors. Nowadays, a decision has already been prepared to subsidize the coupon rate on bond issues released to projects finance to implement the best available technologies.

TABLE I. INVESTMENTS IN FIXED ASSETS AIMED AT ENVIRONMENTAL PROTECTION AND RATIONAL USE OF NATURAL RESOURCES (IN ACTUAL PRICES)

\begin{tabular}{|l|l|l|l|l|l|l|l|}
\hline \multicolumn{1}{|c|}{ Indicators } & $\mathbf{2 0 1 0}$ & $\mathbf{2 0 1 5}$ & $\mathbf{2 0 1 6}$ & $\mathbf{2 0 1 7}$ & $\mathbf{2 0 1 8}$ & $\begin{array}{c}\text { Change, } \\
+,-\end{array}$ & $\begin{array}{l}\text { Growth } \\
\text { rate, \% }\end{array}$ \\
\hline $\begin{array}{l}\text { Investments in fixed } \\
\text { assets aimed at } \\
\text { protecting the } \\
\text { environment and } \\
\text { rational use } \\
\text { of natural resources, } \\
\text { including: }\end{array}$ & 89094 & 151788 & 139677 & 154042 & 157651 & 68557 & 176.9 \\
\hline $\begin{array}{l}\text { protection and } \\
\text { rational use of } \\
\text { water resources }\end{array}$ & 46025 & 78962 & 67469 & 66496 & 62750 & 16725 & 136.3 \\
\hline $\begin{array}{l}\text { \% of total } \\
\text { environmental } \\
\text { investment }\end{array}$ & 51.7 & 52.0 & 48.3 & 43.2 & 39.8 & -11.9 & 77.0 \\
\hline $\begin{array}{l}\text { atmospheric air } \\
\text { protection }\end{array}$ & 26127 & 40120 & 40340 & 60199 & 65475 & 39348 & 250.6 \\
\hline $\begin{array}{l}\text { \% of total } \\
\text { environmental } \\
\text { investment }\end{array}$ & 29.3 & 26.5 & 28.9 & 39.1 & 41.5 & 12.2 & 141.6 \\
\hline $\begin{array}{l}\text { protection and } \\
\text { rational use of } \\
\text { water resources }\end{array}$ & 9340 & 15703 & 12228 & 10216 & 10011 & 671 & 107.2 \\
\hline $\begin{array}{l}\text { \% of total } \\
\text { environmental } \\
\text { investment }\end{array}$ & 10.5 & 10.3 & 8.7 & 6.6 & 6.4 & -4.1 & 61.0 \\
\hline
\end{tabular}

Among the main measures of state support for the green Finance market are the following:

- Ensuring the integrity of the market. The formation of green bond principles and standards at the national level ensures the development of a reliable green market, guarantees government support for green bond issues, and helps investors monitor the level of investment impact on climate change.

- Strategic bond issues. Implementation of the state issue of green bonds to ensure liquidity in the market, attract and study investors. For this purpose, green sovereign, municipal bonds, as well as bonds of development institutions or green banks can be released.

- Derisking. Risk reduction is achieved by scaling up green projects and securitisation loans at the design stage to ensure access to the bond market for 
institutional investors, as well as issuing secured green bonds.

- Cost benefits. There are several types of cost benefits: preferential environmental dues and fees, state guarantees, subsidies, direct state financing at the stage of preparation and design of projects, state insurance, etc.

- Demand guarantee. Guarantee of demand through public procurement with priority for environmental components.

Under the "green" bond program, the state reimburses businesses from 70 to $90 \%$ of their coupon income if the borrowed funds are invested in projects to reduce industrial waste and emissions. The subsidy is provided for bond issues that do not exceed 30 billion rubbles, the amount of the subsidy depends on which equipment is purchased - Russian or foreign. In the case of loans, the rate will also be compensated more if the financing is settled for buying Russian products or technologies. [4]

The Ministry of Industry and Trade of the Russian Federation has prepared decisions to the resolution on subsidizing "green" bonds aimed at supplementing the mechanism with "green" loans.

Support for companies in issuing "green" bonds has been in effect since 2019, but it is still in the start-up mode, shows the distribution of funds in the national project "Ecology". In the 2019 Federal project "Introduction of the best available technologies" (on this item are gone through "green" bonds, there are notes of the expert council on long-term investment market in Central Bank), the budget was supposed to spend only 300 million rubbles in 2020 is planned to 3 billion rubbles, and in subsequent years -6 billion rubbles. [2]

The amount of budget expenditures for the payment of coupon income on "green" bonds for 2019-2024 is set at 27 billion rubbles. Thus, there is the high interest on the part of oil and gas, mining and metallurgical, coal and chemical companies in expanding financial instruments for subsidizing "green" projects."[3] Subsidizing "investment loans" is a simpler and more versatile tool compared to subsidizing coupon payments on bonds.

Projects of small volume or with a long investment phase are more convenient to Finance through the opening of a credit line, rather than by issuing bonds. The subsidy mechanism has not been tested yet. The actual amount of funding will depend on the actual needs of customers and the speed of passing all the approvals provided by the decree. [9]

In lending, banks already have experience in controlling the use of borrowed funds. Banks will be able to "strictly monitor the target spending of funds, which fully fits into the logic of "green" financing". In relation to the notes of such control will be more difficult to implement. The need to create a mechanism for "green" loans is overdue, but there is no approved methodology for assessing such projects in terms of risks. "Often such projects are not profitable, and their implementation period is quite long. The project evaluation process is usually carried out by thirdparty organizations, since banks can not determine whether the company stated effects (reduction of emissions, energy efficiency or efficiency of modernization, etc.) are achievable."

In the Russian market, "green" investments are also unpopular. Three issuers placed such bonds on the Moscow Exchange: "Center-Invest Bank" (the issue volume is 250 million rubbles), "Financial industrial corporation GarantInvest" (500 million rubbles) and "Particularized fiscal association Rusol" (5.7 billion rubbles).

Spending on "green" bonds is only a small part of the money that the government expects will go to «implement the best available technologies." The environmental national project shows that extra-budgetary sources of funding will give to federal project 2.4 trillion rubbles.

Thus, the environmental activities development requires large investments, the financing source which should be mainly budgetary funds, although in a market economy their importance begins to weaken. In the last few years, extra budgetary financing sources have become widespread in Russia- environmental trusts and funds, which in the future may become environmental banks that have as their main function lending to environmental activities.

\section{USING THE TEMPLATE}

The results of the research can be used in the work of state authorities of the Russian Federation in the preparation of normative and methodological acts on evaluating the effectiveness of budget investments in environmental investment projects. The use of the proposed system of financing for these projects and proposals for improving the mechanism for their implementation will allow quick assessment of the progress of priority environmental and economic projects and take timely steps necessary to eliminate the possible lag in the implementation of their individual activities and directions from the plan. In the end, this will allow achieving the targets set by these projects for the development of the environmental sphere in Russia. The results of the study are of interest to specialists in the field of environmental law and environmental and investment policy in General, as well as control and accounting authorities at the Federal, regional and local levels. [11]

Financing of environmental investment projects and integrated environmental programs is usually carried out in a mixed form from the following sources:

1) budget funds;

2) own funds of enterprises (profit, depreciation, reserves, share capital);

3) funds of extra-budgetary environmental funds;

4) environmental insurance funds;

5) Bank loans;

6) funds of citizens, including voluntary contributions from foreign legal entities [6].

Figure 2 shows the structure of financing investments in environmental protection measures. 
The implementation of state tasks is connected with ensuring resource conservation, environmental safety, rational use of natural resources, as well as with the greening of public production and all social activities. To achieve this, first of all, it is necessary to build a constructive dialogue between the state and the business community. As a result of such a dialogue, a mutually beneficial and balanced model of interaction can be formed, which will exclude the possibility of inefficient use of investment opportunities.

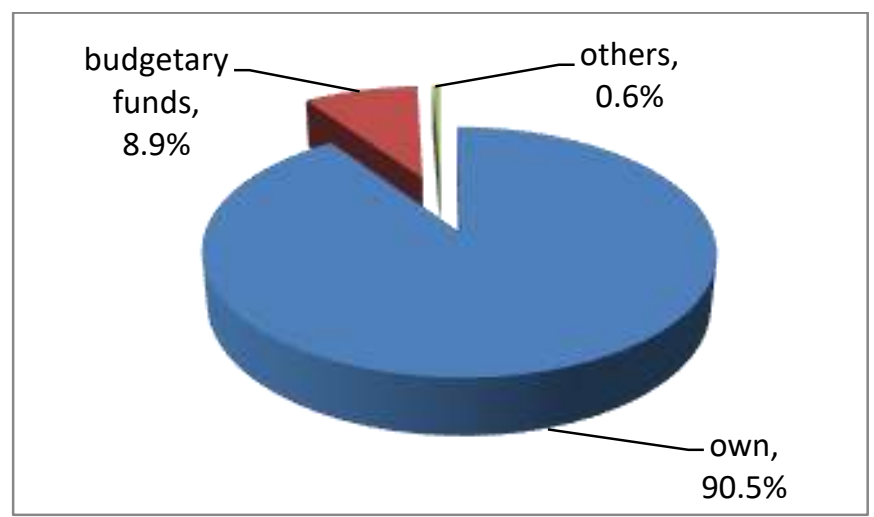

Fig. 1. Distribution of investments in fixed assets aimed at environmenta protection and rational use of natural resources by sources of financing (as a percentage of the total), 2018

Let us consider the main mechanisms of economic stimulation of priority areas of economic activity, developed by the state to build a constructive "environmental dialogue".

One of these tools is state support at the Federal and regional levels for investment activities in the field of rational use of natural resources and environmental protection

In accordance with the legislation at the Federal level state support for investment activities in the implementation of environmental measures provides for:

- tax incentives, which are now an important component of the state's policy in the development of priority industries;

- compensation for expenses related to research and development, including the development of technologies in the environmental field;

- investment tax credit;

- preferential terms of land use, leasing of land plots that are in state and municipal ownership, or land plots that are not divided by state ownership, without bidding with the right to transfer ownership of the land plots that are being exploited;

- preferential lending programs for small and mediumsized businesses (SMEs) within the framework of the Federal project " Expanding access of SMEs to financial resources, including preferential financing»;

- state guarantees of the Russian Federation under credits or bonded loans, involved on realization of the investment projects;
- application of the "green tariff" in the electricity sector;

- issue of green bonds;

- subsidies for reimbursement of part of the cost of paying interest on loans.

State support for investment activities at the regional level is expressed in the form of the following preferences:

- provision of subsidies for reimbursement of part of the costs for the creation of capital construction facilities of engineering infrastructure that are an integral part of the investment project, and (or) for their connection (technological connection) to engineering systems of electricity, gas, water supply and sanitation;

- reimbursement of part of lease payments;

- reimbursement of part of the costs associated with the purchase of equipment;

- exemption from transport tax;

- support for export-oriented industries;

- support (guarantee) of the guarantee funds created by the Executive authorities of the Russian Federation, financed from the budget of a constituent entity of the Russian Federation and the Federal budget and operate (provide guarantee) exclusively in the territory of the constituent entity of the Russian Federation, where created.

Today, the use of new economic approaches in the field of environmental protection is becoming increasingly important. The ecological and economic mechanism can be represented structurally by the following structural elements:

- accounting for natural resources;

- environmental financing;

- limiting, licensing and payment for use of natural resources;

- economic incentives for environmental protection [2].

The main tools of the environmental credit system are preferential terms of environmental credit agreements. Thus, for borrowers who are actively engaged in environmental protection activities, they can claim benefits under an environmental loan in the form of a low rate and a long term loan for the purchase of environmental equipment [11].

In accordance with the national project" Ecology", the tools of the environmental credit system can also include a regime of accelerated depreciation of environmental equipment, which implies an accelerated transfer of the cost of depreciated property to the cost of goods and services produced with its participation. At the same time, the depreciation period is reduced in accordance with the acceleration coefficient, which is a good incentive for environmental activities [4].

In our view, the lending system should be organized in such a way that it is profitable for the enterprise to carry out 
environmental measures, and for banks to issue the necessary loans.

This can be expressed in priority lending on preferential terms (reduced interest rates) for companies that protect the environment. The interest of commercial banks in concessional lending to enterprises that effectively implement environmental protection activities is provided on the condition of full compensation of funds spent by banks on granting concessional loans. Losses of banks can be compensated by providing them with tax incentives, as well as issuing state subsidies to cover costs [10].

Economic incentives for environmental functions can be implemented:

a) preferential taxation of environmental measures reduction of nature intensity of production;

b) bonuses for the implementation of efficient environmental measures;

c) introduction of accelerated depreciation of environmental assets;

d) concessional lending and the issuance of special lowinterest loans for the purchase of abatement equipment and the introduction of low-waste technologies [3].

Benefits related to activities of environmental significance can be provided not only on the initiative of the state, but also by other entities. Attracting Bank loans to Finance environmental activities allows simultaneous solution of several problems, for example, the identification of the advantages of Bank lending in comparison with budget financing, consisting in the repayment and payment of funds provided. This will help to increase the efficiency of their use and reduce the duration of environmental protection work. In addition, it is possible to direct budget funds to Finance other activities, since in this case, the budget will cover only the budget grant provided to the Bank that lends environmental measures [6].

Enterprises effectively engaged in the protection of the environment, are entitled to preferential loans. Banks that provide such loans, in turn, have tax incentives, subsidies, as well as preferential interbank loans. Environmental funds are exempt from taxation, since their funds are intended for enterprises and organizations to conduct environmental activities. The use of environmental funds is carried out on contractual terms under interest-bearing loans [8].

The system of environmental taxation also includes payment for a loan for environmental funds. Environmental lending should be of a concessional nature, and therefore the loan fee will be relatively small, but it should be made dependent on the term of disbursement of funds; exceeding the standard term of disbursement significantly increases the rate of payment for the loan. And the commissioning of a company that has received a loan without environmental protection devices is punished, among other sanctions, by a high penalty interest for the loan. There are special penalties for serious environmental violations - multiple accidental releases and discharges of dangerous pollutants, non-compliance with environmental safety measures, exceeding contractual quotas for greenhouse gas emissions, and violation of agreements on the transboundary transfer of pollutants.

The law of the Russian Federation" On environmental protection " provides for the possibility of preferential lending to enterprises, institutions and organizations, regardless of their ownership forms, that are effectively engaged in environmental activities [5].

Thus, in order to prioritize environmental issues, it is necessary to introduce a system of economic incentives for environmental activities, including:

- preferential taxation,

- concessional lending and subsidizing of nature protection projects,

- accelerated depreciation of environmental fixed assets.

So, in order for the environmental management system at the enterprise to become an effective tool for local environmental management, economic (for example, preferential payments, or preferential credit terms) and other mechanisms of state support should be provided, which would ensure the interest of the enterprise in systematic methods of environmental management.

The source of compensation for losses of banks can be budget allocations and funds of environmental funds. Grants can be provided by financing preferential interest rates on loans for environmental purposes at the expense of budget funds. Operations for crediting environmental measures become equally profitable in terms of the amount of profit received compared to operations for providing other loans.

Thus, the development of environmental activities, which usually require large investments, the source of financing of which is mainly budget funds, in a market economy, their importance begins to weaken. In recent years, extra budgetary sources of financing have become widespread in Russia- environmental loans and funds, which in the future may become environmental banks that have as their main function lending to environmental activities.

\section{CONCLUSION}

The considered measures of state support for investment activities in the implementation of environmental protection measures, their combination create favorable conditions for building a constructive "ecological and economic dialogue" between the state and industrial enterprises, organizations engaged in waste management, water use, and cleaning of industrial emissions.

The study systematizes modern sources of financing for environmental projects, presents their advantages and disadvantages. The relevance of state support for sources of financing of investment activities in the field of environmental protection is substantiated. The organization of financing of environmental activities of enterprises is one of the important factors in improving environmental performance. The formation of investment resources is the main condition for the implementation of environmental projects by industrial companies. Solving the problem of financial support for 
environmental measures at the present stage will lead to sustainable economic growth of the country in the medium and long term.

Investments in environmental protection activities of enterprises are understood as long-term investments of money and other capital in their own country or abroad in enterprises of various types of economic activity, entrepreneurial projects, socio-economic programs, innovative projects with an environmental focus, in order to generate income and/or achieve a positive socio-environmental effect. The process of investing in environmental protection depends directly on the available sources of funding for projects, programs and activities. Currently there are sources of financing for environmental projects with identification of their positive and negative sides.

\section{References}

[1] About environmental protection: N7-FZ of 10.01.2002. "ConsultantPlus".

[2] E.E. Bichyova, L.N. Sotnikova, "Environmental efficiency of investment projects in agriculture", Vest. of The Voronezh State Agrar. Univer., vol. 3, no. 58, pp. 183-189, 2018.

[3] E.E. Bichyova, L.N. Sotnikova, L.N. Maslova, "Investment development of agro industrial complex based on the demands of environmental safety", Coll. IOP conf. ser. Earth and environmental sci. the proc. of the conf. agrocon., p. 012213, 2019.

[4] M. Chesney, J. Gheyssens, A. Claudia Pana, L. Taschini, "Environmental finance and Investments", in: Springer Texts in Business and Economics. Berlin: Springer-Verlag, 2016, 123 p.

[5] Ecological banks, ECO-banks. Retrieved from: http://oooekotrest.ru/ statyi-info-musor/265-eco-banki.html (accessed 13.02.2020).

[6] Environmental programs of Russian credit organizations. Retrieved from: http://bankir.ru/publikacii/20131007/zelen-v-banke-10004032/ (accessed 13.02.2020).

[7] Financing of environmental projects and programs at the international level-url. Retrieved from: http://txtb.ru/23/14.html (accessed 13.02.2020).

[8] National project "Ecology" (approved by the decision of the Presidium of the presidential Council for strategic development and national projects on 24 December 2018). "ConsultantPlus".

[9] On environmental protection, Federal law no. 7-Federal Law of 10.01.2002 (adopted by the National Duma on December 20, 2001). "ConsultantPlus".

[10] G.F. Yusupova, M.M. Mardanova, "Classification of environmental investments", Probl. and prosp. of econ. and manag., pp. 69-72, 2014 [Mater. of the III Int. sci. Conf.] St. Petersburg, December 2014. Retrieved from: https://moluch.ru/conf/econ/archive/131/6843/ (accessed 13.02.2020).

[11] L. Zaporozhtseva, T.V. Sabetova, Yu.V. Tkachyova, "Developing and testing model for investment risk assessment in agriculture", Advan. in Engineer. Res., pp. 802-806, 2018. 